\title{
Ecofloristic Diversity of Gopegarh - A Historic Place of Paschim Medinipur District of West Bengal
}

\author{
Goutam Bhakta, Shri J.J.T University \\ Chudela, Jhunjhunu 333001, Rajasthan
}

\begin{abstract}
Gopegarh is a place of historic of Paschim Medinipur District, is situated on the bank of River Kangsabati. The Elevation is $211 \mathrm{ft}$ or $64.30 \mathrm{mt}$. It lies between $22^{\circ} 57^{\prime} 10^{\prime \prime}$ North latitude and 87016'50" East longitude. There was a fort in the ancient past and had dense jungles. The plenty of vegetation of the past becoming dry bare rocky area following year after years. We should take the initiative immediately to save the ecofloristic diversity.
\end{abstract}

\section{Introduction}

Gopegarh is a deciduous forest belt, recently forest cover has been affected by the human beings of different cultures. Human population encroaches the forest range of Gopegarh and disturbing the floral development. Many plant species are being fewer or rare day by day. Such information will be useful in forestry, horticulture, pharmaceutical industry, cultivation of medicinal and other economic plants, soil conservations and study of vegetation, environmental protection and other allied aspects. As such the present work will be of much value and would substantially contribute considerable data in detail for the flora of Paschim Medinipur District and West Bengal state as well. The temperature in the winter is10, in the summer 43 in the rainy season there is an appreciable cooling temperature 32-35. The annual rainfall is about $1500 \mathrm{~mm}$ $1750 \mathrm{~mm}$.It belongs to laterite soil or red soil.Reddish brown and yellowish soil are prominent in the upland and grey soils occur in some low lying pockets or fields.Soil is generally acidic( $\mathrm{pH} 5.0$ ), calcium,potassium, phosphorous are lower in content.

\section{Material \& Methods}

During the course of investigation various localities of Gopegarh of Paschim Medinipur District belonging to the state of West Bengal of India was explored for collection of Plant materials including fruits, seeds of herbs, shrubs and trees. Collecting trips were planned in order to cover as much as possible the diversity of various herb, shrub and tree taxa. Collections have been made out of one day trip.

For collection of specimens and taking field data during survey, several attempts were made in different seasons of the year 2015-2016. In each collection trip the assistance of local people were sought. These people assisted in plant collection in various ways, Medicinal values, economic uses, ethnic criteria of the plants if any have been gathered from the local peoples as far as possible during collection of specimens.

\section{Results}

The vegetation of Gopegarh Tropical ecosystem has interesting floral diversity and vegetation due to its variable topography, soil and climate. This zone consists of lower undulating plateau, depression of plateau, lowlands, cultivated lands neglected orchards, pond, river, natural lawn, park etc. The plateau areas are covered with mixed forest consisting of many deciduous and evergreen species like Shorea robusta, Tectona grandis, Terminalia bellerica, T. chebula, T. arjuna, Eucalyptus acacia, Anacardium, madhuca indica, Aegle sp., Boswellia serrata etc are trees. The lianes like Bauhunia vahlii, Butea superba, Ichnocarpus forming dense bushes in certain places.

Along the nalas, gullies and slopes Saccharum spontaneum, S. munja, Heteropogon contortus, Flegmaria chapper, Breynia rhamnoides, Thysanolaena maxima etc are common. The evergreen trees Strychnos nuxvomica, Bucanamia langum.

The climbers like smilax zeylanica, Dioscorea, Gymnema, Cocculus, Vitis, Mikania,Passiflora foetida, Tinospora cordifolia, Bryonia lacenosa etc. are found in the jungle near the road sides and villages. Due to intensive felling and grazing the top soil of the plateau and gullies become exposed and eroded at rapid rate.

The cultivated lands near the river bank are used for cultivation of rice, wheat, potato, cabbage, mustard, ladies finger, gourd, pulse, and different other vegetables e.g Capsicum, Cicer, Cucumis Lycopersicon, Raphanus Momordica.etc. Low lands and pond are usually filled up with water for 4-5 months upto Nov-Dec., some aquatic plants are found to grow in these wet places, eg. Alternanthera, Apluda mutica, Cleome viscosa, Physalis minima , Sp of Sida, Solanum, Rumex dentatus, Vernonia, Cyperus sp, Dactyloctenium, Vandelia, 
Scirpus articulatus, Mazus pumilus, Eleusine indica, Ludwigia perviflone, Eragrotis tenella, Chloris barbata, Cyanodon dactylon, Chrysopogon aciculatus, Eclipta alba, Alternanthera sessilis, Ammania baccifera etc. Irrigated crop fields are filled up by water and plants like Monochoria hastata, Sagittaria trifolia, species of Scirpus Fimbristylis barbata, Polygomum barbatum, Species of Cyperus, Commelina benghalensis, Tradescantia sp, Echinochloa colona, Species of Eragrostis etc.

During winter the common weeds in these fields are Anagallis arvesis, Chenopodium album, Coronopus didymus, Fumaria parviflora, Medicago lupulina, M. Polymorpha, Melilotus alba, M.indica, Polygonum plebejum, Solanum nigrum, Trianthema portulacastrum, Vicia hirsuta etc.

In the forest sal and teak plants are dominating. The chief associates of this dry deciduous sal and teak bearing forest are Haldinia cordifolia, Lagerstroemia parviflora, Madhuca indica, Oroxylon indicum, Pterocarpus marsupium,Dalbergia sissoo, Terminalia bellirica, T. Chebula, Agle mermerlos ,Bridelia retusa, cassia fistula, Albizia procera, A lebeck, Flacourtia indica, Holarrhena antidysentarica, Dalbergia sisso, Phyllanthus emblica, etc. The under growth includes Clerodendrum viscosum, Flacourtia indica, Hyptis snaveolens, Lantana camara, Zizyphus mauritiana, Woodfordia fruticosa, Eupatorium odoratum, Lippia geminata etc. The ground cover includes Achyrarthesaspera, Andrographis paniculata, Aristada setacea, different species of Cyperus, Euphorbia hirta, E microphylla, Spermacoce hispida, Oldenlandia corymbosa, Tephrosia purpurea, T. villosa, Phylla nodiflora, Vandellia crustacea, Rungia pectinata, Alysicarpus monilifer, A.vaginalis, A. rugosus Mollugo spergula, Mollugo oppositifolius, Dentella repens, Evolvulus numularius, E.alsinoides etc.

The epiphytic orchids are rare and is represented by Vanda roxburghii only.

Among parasites, Cuscuta reflexa grow on the branches \& bushes, and rarely Dendropthoe falcata grow on the tree trunk.

The Dry mixed deciduous plants are deciduous during the dry season are Butea monosperma, Bombax ceiba, Lagerostromia parviflora, Terminalia arjuna, T.chebula, T.bellerica, Anacardium occidentale, Cassia fistula, Madhuca indica, Phyllanthus emblica, Aegle mermelos etc.The poor moisture retaining capacity of soil shows the stunted growth of plants like Alangium lamarkii, Streblus asper, Flacourtia indica etc. The Govt. has taken the steps to cultivate the cheshewnut. Several hectors cheshewnut cultivation supervised by Forest division.

Besides the forest vegetation, a good number of plants are found to occur in various places like, Jungles, road side, river bank, villages etc. Some plants may be mentioned, Glycosmis pentaphylla, Costus speciosus, Cordia bixa, Rauvolfia cansescens, Justisia genderusa, Peristrophe bicalyculata, sp of Disoscorea, Cissus repanda, Cayratia trifolia, Cissampelos pareira, Coccinia grandis, Luffa cylindrica, Mikania scandens, Tinospora cordifolia, Trichosanthes anguina, Parthenium hystoriphorus, Commelina benghalensis etc. Gmelina arborea, Mangifera india, Millingtonia hortensis, Adenanthera pavonina, Polyalthia longifolia, Tamarindus indicus, Pongamia pinnata, Dalbergia sissoo, Lantana camara, Phoenix sylvestre, Borassus flavelifer, Tridax procumbens, Xanthium strumarium etc.

The plants grow on the walls-are Bidens pillosa, Lindenbergia indica, Vernonia cineria, Peperomia pellucida, Pilea microphylla, Portulaca oleracea, Tridax procumebens, Triumfetta rhmoboidea etc. Reverain vegetation along the courses of river belts Sandy and rocky river belts are composed of some common trees, shrub, and herbaceous flora.

The state Govt. Eco-tourism Department established a park "Ecopark" in the heart of Gopegarh. Several trees, shrubs and showy herbaceous plants have planted in the park. Many season foloweing plants are planted during the specific season. Thuja, Casuarina, Polyalthia, Cassia glance, Peltorhorum innerme, Delonix regia, Cassia fistula, Caesalpinia pulcherrima, Eucalyptus globulus, Pterospermum acerifolium, Tecoma sp, Parkinsonia aculeata, Alstonia scholaris, Alamanda sp. etc. have planted in the park. Govt. also built up the many resorts in the park for the tourists.

\section{Discussion}

The marginal people from the villages particularly the tribal peoples always cutting down the trees and branches. The forest is easily accessible and due to unrestricted hacking and over exploitation of some plants continued for years - the forest have been reduced to scrubs. Extremely xerophytic conditions have set in the conditions becoming more and more xerophytic.

\section{Conclusion}

Gopegarh is a place of historic interest Govt. and other agencies at present encroaching inside of it for their purposeful interest and hampering the ecofloristic diversity. The plenty of vegetation of the past becoming dry are rocky area following year after years. Details and thorough research works are essential right now to know the present situation about the loss and causes of loss of ecofloristic diversity. Govt. should take the initiative immediately to save this diversity of Gopegarh. We think out limited work is befitting but not least at this high crucial time. Hope future research works will direct a new avenue to save the ecofloristic diversity of Gopegarh. 


\section{Reference}

[1] Jain, S.K. and Rao, R.R., 1977. A handbook of Field and Herbarium Methods. Today and Tomorrow's printers and Publishers, New Delhi.

[2] Maji, S \& J.K.Sikdar (1982) A taxonomic survey of edible wild plants of Midnapur District.

[3] Maji, S.1978-Flora of Midnapur District. Thesis

[4] Paria N.D. 2005, Medicinal Plant resources of South West Bengal, Directorate of Forests. Govt. of West Bengal, Kolkata.

[5] Watt, G. 1972. A dictionary of the Economic Products of India 4(4) : 207, Delhi (Reprinted) 